\title{
НОРМАТИВНО-ПРАВОВЕ РЕГУЛЮВАННЯ ПИТАНЬ ЗАБЕЗПЕЧЕННЯ БЕЗПЕЧНОГО СЕРЕДОВИЩА ДЛЯ ЖИТТЯ ГРОМАДЯН
}

Федорова $\boldsymbol{A}$. М., аспірант, Національний університет біоресурсів та природокористування України м. Київ, Україна

У статті розкрито змістовне навантаження понять «безпека», «безпека життєдіяльності», «цивільний контроль». Проаналізовано види безпеки та встановлено, щчо виокремлюють такі види безпеки: безпеку людини; національну безпеку, щуо складається $з$ державної безпеки, безпеки політичної, економічної, воєнної, технологічної, екологічної, гуманітарної, демографічної, інформачійної, банківської, продовольчої, енергетичної тощзо; безпеку життєдіяльності, складовими якої є: безпека праці, безпека військової служби, громадська безпека, безпека харчових продуктів, безпека особиста та ін. Показано, щуо безпека являє собою досить суперечливий, довгостроковий феномен політичної сфери суспільного життя. Наголошено, щзо специфіка політичного розвитку ставить питання про наростання проблем захисту національних інтересів, щзо вимагає не механічного нарощування зусиль в тому чи іншому загрозливому напрямку, а переосмислення засад функиіонування системи забезпечення національної безпеки.

Здійснено огляд нормативно-правових актів, щзо регулюють питання забезпечення безпеки в державі, суспільстві і безпеки громадянина. 3'ясовано складові, які забезпечують умови безпечного середовища для населення Украӥни.

Ключові слова: безпечне середовище; безпека; безпека життєдіяльності; громадськість; громадська безпека.

Постановка проблеми у загальному вигляді. Становлення правової держави складний суперечливий процес. Поряд 3 оче- 
видними досягненнями у демократизації суспільного життя, лібералізації економіки розвиток України характеризується наявністю деструктивних явищ, які суттєво гальмують здійснення соціальноекономічних реформ, що ставлять під загрозу законні права та інтереси громадян, суспільства, держави загалом. Тому не випадкова підвищена увага сучасної науки до проблеми забезпечення безпеки. Пошук шляхів розв'язання існуючого протиріччя між очікуваним станом захищеності та його реальним здійсненням - одне 3 основних завдань держави.

Громадські об'єднання в Україні є політико-правовими інститутами, що розвиваються та виконують посередницьку функцію між громадянським суспільством і публічною владою щодо забезпечення та захисту прав і свобод громадян, а також їх інтересів та ініціатив. При цьому в такій важливій для сучасної України проблемі, як забезпечення безпечного середовища життя, інтереси держави та суспільства збігаються. Це зумовлено насамперед тим, що держава зобов'язана своїм походженням суспільству і розвивається разом 3 ним. Тому представляється особливо актуальним дослідження питання про взаємодію держави в особі їі органів 3 громадянськими об'єднаннями в такій сфері, як забезпечення безпеки.

Наразі в повну силу заявила про себе наукова проблема, що полягає в необхідності подолання невідповідності наявного теоретичного та емпіричного обгрунтування процесу забезпечення безпеки новим гострим і складним вимогам до формування ефективних інститутів і технологій вирішення завдань безпеки в XXI столітті. Серед причин, що визначають особливу увагу до аналізу взаємодії держави і суспільства у сфері протидії загрозам безпеки, головною $\epsilon$ безпосередній вплив підсумків таких досліджень на добробут конкретних людей в динамічних і суперечливих умовах суспільства, що трансформується в Україні. Наразі ситуація у сфері забезпечення безпеки принципово змінилася, що зумовило необхідність глибокого теоретичного осмислення попередніх підходів і постулатів. За останні роки накопичено чималий досвід реформ у сфері безпеки, створено законодавчу базу, сформовано нову структуру органів іiі захисту. Тим не менш динаміка розвитку сучасної української дер- 
жави і громадянського суспільства, процеси, що протікають у світовому співтоваристві, породжують безліч нових загроз безпеці, які повинні знайти адекватне організаційно-правове рішення в адміністративно-політичній сфері державного управління.

Необхідно також брати до уваги, що безпека являє собою досить суперечливий, довгостроковий феномен політичної сфери суспільного життя. Специфіка політичного розвитку ставить питання про наростання проблем захисту національних інтересів, що вимагає не механічного нарощування зусиль в тому чи іншому загрозливому напрямку, а переосмислення засад функціонування системи забезпечення національної безпеки.

До теперішнього часу серед вчених, які досліджують проблеми безпеки, не вироблено загального підходу до визначення основного понятійного апарату з зазначеної проблематики, включаючи основні параметри співпраці влади та інститутів громадянського суспільства щодо протидії загрозам особистості, суспільства і держави.

Фахівці та науковці в Україні намагаються шукати нові дієві шляхи забезпечення безпеки національної, безпеки життєдіяльності тощо. До цих наукових доробок долучилися і представники громадянського суспільства, всі небайдужі громадяни України. Зокрема дана стаття безпосередньо пов'язана із науковими дослідженнями кафедри публічного управління та менеджменту інноваційної діяльності ННІ післядипломної освіти Національного університету біоресурсів та природокористування України.

Аналіз досліджень і публікацій. Нині існує велика кількість наукових праць, які висвітлюють питання забезпечення безпечного середовища для життя громадян. Серед науковців, які досліджували цю проблематику варто виділити В. Авер'янова, В. Доненка, I. Коліушко, В. Колпакова, О. Кузьменка, В. Погорілко, Ю. Фоміна, Л. Шевченка та ін. Проте досі є недостатньо дослідженими питання діяльності органів влади із забезпечення основних прав і свобод громадян України крізь призму суб'єктивного відчуття населенням захищеності та безпечного середовища для життя.

Формулювання цілей статті (постановка завдання). Метою статті є розкриття змісту понять «безпека», «безпека життєдіяль- 
ності», «цивільний контроль» виокремлення видів безпеки та їх нормативно-правове унормування.

Виходячи з мети в статті вирішувалися такі завдання:

- проаналізувати змістовне навантаження понять «безпека», «безпека життєдіяльності», «цивільний контроль»;

- виокремити види безпеки;

- здійснити огляд нормативно-правових актів, що регулюють питання забезпечення безпеки в державі, суспільстві і безпеки кожного громадянина.

Виклад основного матеріалу дослідження. 21 червня 2018 року було прийнято нову редакцію закону «Про національну безпеку України» [1]. Цей Закон відповідно до статей 1, 2, 17, 18 і 92 Конституції України [2] визначає основи та принципи національної безпеки і оборони, цілі та основні засади державної політики, що гарантуватимуть суспільству і кожному громадянину захист від загроз. Конституція України визначає, що людина, її життя і здоров’я, честь і гідність, недоторканність і безпека визнаються в Україні найвищою соціальною цінністю. Утвердження і забезпечення прав $\mathrm{i}$ свобод людини є головним обов'язком держави.

Громадська безпека у цьому законі визначається наступним чином: «захищеність життєво важливих для суспільства та особи інтересів, прав і свобод людини і громадянина, забезпечення яких $\epsilon$ пріоритетним завданням діяльності сил безпеки, інших державних органів, органів місцевого самоврядування, їх посадових осіб та громадськості, які здійснюють узгоджені заходи щодо реалізації і захисту національних інтересів від впливу загроз» [1].

Статтею 1 цього закону передбачено, крім іншого, і введення нового документу - Стратегії громадської безпеки та цивільного захисту України, який направлений на довгострокове планування i розробляється на основі Стратегії національної безпеки України за результатами огляду громадської безпеки та цивільного захисту і визначає напрями державної політики щодо гарантування захищеності життєво важливих для держави, суспільства та особи інтересів, прав і свобод людини і громадянина, цілі та очікувані результати ïх досягнення з урахуванням актуальних загроз [1, ст. 1]. 
Крім цього, ст. 4 Закону України «Про національну безпеку України» встановлює засади демократичного цивільного контролю та визначає, що систему цивільного контролю складають: контроль, що здійснюється Президентом України та Верховною Радою України; контроль, що здійснюється Радою національної безпеки і оборони України; контроль, що здійснюється Кабінетом Міністрів України, органами виконавчої влади та органами місцевого самоврядування; судового контролю; громадського контролю [1, ст. 4].

Новий закон цілком відповідає поставленим вимогам, зрозуміло, $з$ деякими застереженнями, і в числі інших істотно змінив принципи забезпечення безпеки.

Загальновідомо, що принципи є центральним поняттям, основою системи, яка представляє узагальнення і поширення якого-небудь положення на всі явища тієї галузі, в якій даний принцип абстрагований. Одним з принципів Закону України «Про національну безпеку України» є принцип взаємодії органів державної влади 3 громадськими об'єднаннями в цілях забезпечення безпеки. Таким чином, законодавець закріпив взаємодію органів державної влади 3 громадськими об'єднаннями в цілях забезпечення безпеки у якості правового принципу.

Нині державні органи, які покликані забезпечити безпеку в різних сферах, самі частково дезорганізовані й на даний момент не здатні повністю впоратися з усім різноманіттям завдань забезпечення безпеки. Гостро відчуваючи свою незахищеність, суспільство безпосередньо, без посередництва держави, намагається зробити кроки у плані забезпечення власної безпеки шляхом створення численних громадських об'єднань. Як правило, створення цих об'єднань відбувається мимовільно і є реакцією громадян на реальне або ймовірне виникнення загроз і небезпеки їх традиційному способу життя, матеріальним і духовним запитам та інтересам.

Що ж таке безпека? Загальновідомо, що безпека - це такі умови, в яких перебуває складна система, коли дія зовнішніх факторів і внутрішніх чинників не призводить до процесів, що вважаються негативними по відношенню до даної складної системи у відповідності до наявних, на даному етапі потреб, знань та уявлень. 
Вирізняють такі види безпеки:

- безпека людини - такий стан людини, коли дія зовнішніх та внутрішніх факторів не призводить до смерті, погіршення функціонування та розвитку організму, свідомості, психіки та людини в цілому і не перешкоджає досягненню певних бажаних для людини цілей;

- національна безпека - захищеність життєво важливих інтересів людини і громадянина, суспільства і держави, за якої забезпечуються сталий розвиток суспільства, своєчасне виявлення, запобігання і нейтралізація реальних та потенційних загроз національним інтересам. Складовими національної безпеки є:

- державна безпека;

- політична безпека;

- економічна безпека;

- воєнна безпека;

- технологічна безпека;

- екологічна безпека;

- гуманітарна безпека;

- демографічна безпека;

- інформаційна безпека;

- банківська безпека;

- інвестиційна безпека;

- продовольча безпека;

- енергетична безпека та ін.

- безпека життєдіяльності - спрямована на захист здоров'я та життя людини і середовища іï проживання від небезпек. Складовими безпеки життєдіяльності є:

- безпека праці;

- безпека військової служби;

- громадська безпека та ін.

- безпека конкретних видів діяльності (ядерна безпека, гірнича, віброакустична тощо);

- безпека харчових продуктів;

- безпека споруд і об'єктів - властивість споруди не створювати загрозу для життя, здоров'я та інтересів людини (техногенна безпека, пожежна, радіаційна тощо); 
- безпека особиста;

- безпека побутова.

Перш ніж розглянути практичні питання взаємодії державних органів з громадськими об'єднаннями в цілях забезпечення безпеки, необхідно звернутися до теорії питання і визначитися, що ж чинне законодавство розуміє під терміном «безпека».

Конституція України в ст. 16 вказує на забезпечення екологічної безпеки і підтримання екологічної рівноваги на території України. Ст. 17 передбачає, що захист суверенітету і територіальної цілісності України, забезпечення іiї економічної та інформаційної безпеки $є$ найважливішими функціями держави. Ст. 39 Конституції України визначає, що громадяни мають право збиратися мирно, без зброї і проводити збори, мітинги, походи і демонстрації. Ст. 42 гарантує, що держава захищає права споживачів, здійснює контроль за якістю і безпечністю продукції та усіх видів послуг і робіт. Ст. 49 конкретизує, що кожен має право на охорону здоров'я, медичну допомогу. Держава забезпечує санітарно-епідемічне благополуччя. Ст. 50 гарантує, що кожен має право на безпечне для життя і здоров'я довкілля. Кожному гарантується право вільного доступу до інформації про стан довкілля, про якість харчових продуктів і предметів побуту. Ст. 55 вказує, що кожен має право будь-якими не забороненими законом засобами захищати свої права і свободи від порушень і протиправних посягань тощо [2].

Незважаючи на те, що ст. 64 Конституції України передбачає в умовах воєнного або надзвичайного стану окремі тимчасові обмеження конституційних прав і свобод людини і громадянина, останні формують гарантовану державою безпекову складову для життєдіяльності населення [2].

Отже, узагальнюючи умови безпечного середовища для населення України, із врахуванням положень Основного закону можемо виокремити такі його складові:

1) життя і здоров'я, честь і гідність, недоторканність і безпека особи;

2) суверенітет і територіальна цілісність, економічна безпека держави, запобігання тероризму;

3) цивільний захист населення; 
4) соціальний захист особи;

5) гарантії права приватної власності, інтелектуальної власності, підприємницької діяльності;

6) гарантії безпеки та свободи пересування особи, свободи слова (безпечне інформаційне середовище), реалізація права на мирні зібрання;

7) безпека споживача продукції (продуктів, предметів побуту) та послуг (робіт), охорона праці;

8) охорона здоров’я, медична допомога та санітарно-епідеміологічне благополуччя;

9) екологічна безпека, безпечне для життя і здоров'я особи довкілля;

10) гарантії правового захисту та права самозахисту особи від порушення її прав, свобод і протиправних посягань.

Для цілей цієї статті важливо окреслити поняття громадська безпека, яке трактується, як стан захищеності громадянського суспільства, що характеризується відсутністю небезпеки для життя та здоров’я людей, для їх спокою та майнових прав, для нормальної діяльності підприємств, установ та організацій незалежно від форм власності, для цілісності й збереження матеріальних цінностей.

Вітчизняне законодавство надає дещо розширене трактування даного терміну і визначає, що громадська безпека і порядок - це захищеність життєво важливих для суспільства та особи інтересів, прав і свобод людини і громадянина, забезпечення яких $є$ пріоритетним завданням діяльності сил безпеки, інших державних органів, органів місцевого самоврядування, їх посадових осіб та громадськості, які здійснюють узгоджені заходи щодо реалізації і захисту національних інтересів від впливу загроз.

Система зв'язків та відносин, яка і представляє суть громадської безпеки, складається відповідно до техніко-юридичних норм під час придбання та використання об'єктів, які становлять підвищену небезпеку для життя та здоров'я людей, майна (державного, колективного чи особистого), а також з початком особливих надзвичайних умов, пов'язаних зі стихійними лихами та іншими надзвичайними обставинами. 
3 кінця 1990-х років в Україні став активно вживатися термін «національна безпека», при цьому він не мав тоді законодавчої основи, так як Конституція і чинне на той момент законодавство не містили такої категорії.

По мірі вживання в науці, політиці і в засобах масової інформації термін «національна безпека» став загальновживаним і наразі інтерпретується як: «захищеність державного суверенітету, територіальної цілісності, демократичного конституційного ладу та інших національних інтересів України від реальних та потенційних загроз».

Наразі під національною безпекою розуміють сукупність державної, громадської, екологічної, економічної, інформаційної та інших видів безпеки.

Характеризуючи систему управління у сфері формування безпечного середовища для життєдіяльності, варто виокремити різноманітність суб'єктів, наділених владними повноваженнями. Вони мають широке коло повноважень, частина яких стосується управління правоохоронними органами щодо забезпечення ними публічного порядку (правоохоронну складову), а інша частина - має на меті створення безпечного середовища для життєдіяльності людей (безпекову складову), тобто усунення всіх чинників, які негативно впливають на стан публічної безпеки та безпеки конкретних осіб чи населення загалом.

В українському праві публічною владою визнається: а) влада народу як безпосереднє народовладдя; б) державна влада - законодавча, виконавча, судова; в) місцеве самоврядування [4]. Публічну владу в Україні здійснюють такі органи: Верховна Рада України (парламент), Президент України (як владний інститут), місцеві ради; усі органи й установи, що реалізують державну владу, усі органи і установи, що реалізують місцеве самоврядування. Відтак публічна адміністрація - це система організаційно-структурних утворень, які на законних підставах набули владних повноважень для їх реалізації в публічних інтересах [5]

Забезпечення безпечного середовища для життєдіяльності населення - це функція суб'єктів публічного адміністрування, яка полягає у формуванні таких суспільних відносин, за яких усуваються 
чинники, що загрожують фізичній та психологічній безпеці людини.

На нашу думку, питання забезпечення національної безпеки, як правило, зводиться до забезпечення державної безпеки з притаманними їй конспірацією, державною таємницею i, звичайно, вузького кола суб'єктів іiі забезпечення. Саме тому, на наш погляд, зокрема, автори коментарів до закону та іншої наукової літератури з даної проблематики обходять питання практичної участі інститутів громадянського суспільства у забезпеченні безпеки [6].

Насправді ж не слід забувати, що національна безпека - це і громадська, і екологічна, і економічна, і пожежна, та інші види безпеки, що представляють собою широкий комплекс питань, що передбачають широку участь громадських об’єднань та інших інститутів громадянського суспільства. Таким чином, пропонується розглядати участь громадських об'єднань у забезпеченні національної безпеки в самому широкому сенсі $[7 ; 8]$.

Національна безпека $є$ одним 3 пріоритетних факторів, що впливають на зміст і динаміку взаємовідносин між державними та громадськими інститутами; іiі політична специфіка полягає в тому, що даний чинник не локалізується тільки в структурі державного управління, але здатний проявляти себе в організаційних формах громадянського суспільства. Процес політичної трансформації породжує різні вимоги до системи забезпечення першочергових потреб громадян, які повинні бути адекватні масштабам і характеру загроз, що виникають. Це вимагає розширення інформаційно-дослідницького поля у сфері безпеки, продовження наукової роботи над виробленням критеріїв іiї забезпечення, а також над побудовою ефективної системи практичній діяльності по організації захисту національних інтересів країни за допомогою організації ефективного, адекватного сучасним умовам, процесу взаємодії інститутів державної влади і формування громадянського суспільства.

Функція забезпечення безпеки, традиційно будучи одним із завдань політики і індикатором ефективності публічної влади, в першу чергу реалізується у діяльності державних інститутів, метою яких виступає створення механізмів, що обмежують і перешкоджа- 
ють неприпустимим проявам загрозливих станів і дестабілізаційних процесів, через що забезпечення безпеки пов'язано з обмежувальними і заборонними заходами і вимагає спеціальних форм і методів діяльності відповідних суб'єктів. Зростання суспільних потреб і ускладнення інтересів громадян і соціальних спільнот на сучасному етапі політичного розвитку, ініціює самодіяльну активність населення, спрямовану на запобігання загроз по відношенню до першочергових потреб життєдіяльності. Це актуалізує необхідність в оптимізації взаємовідносин різнорідних суб'єктів, що функціонують в системі забезпечення національної безпеки.

Наявність відмінностей між органами політичної влади, інститутами громадянського суспільства, а також плюралізму серед індивідів, великих соціальних агрегацій з приводу принципів, норм і стратегії забезпечення безпеки особистості, суспільства і держави на практиці призводить до виникнення громадських об'єднань, які сприяють забезпеченню безпеки, які слід визначати як специфічний інститут громадянського суспільства, який виступає продуктом самодіяльної активності населення, ставить своєю метою визначення принципів та реалізацію політики з протидії загрозам національним інтересам, що володіє інтелектуальними, матеріальними і силовими ресурсами для здійснення намічених завдань, що практично виявляється в можливості формувати дієздатні суб'єкти недержавної системи забезпечення безпеки.

Виходячи 3 накопиченого теоретико-методологічного інструментарію доцільно охарактеризувати процес взаємодії держави і громадських об'єднань у сфері національної безпеки - як заснованої на конституційних нормах системі взаємної підтримки, взаємодопомоги і партнерства між елементами державної системи захисту безпеки та інститутами громадянського суспільства, що володіють ресурсами та потенціалом у справі протидії загрозам національним інтересам, забезпечує необхідний рівень захищеності всіх сфер життєдіяльності народу України.

3 боку органів державної влади до теперішнього часу необхідна осмислена методологічна основа щодо здійснення взаємодії 3 об'єднаннями громадян, які сприяють забезпеченню національної 
безпеки, що повинно дозволити знаходити адекватне втілення самодіяльним громадським ініціативам, спрямованим на вирішення актуальних проблем державної, суспільної та особистої безпеки. Реальні параметри співпраці громадських об'єднань 3 органами державного управління визначається комбінаціями, які залежать від особистісного фактора, миттєвої кон'юнктури, набору ситуативних моментів. 3 іншого боку для громадських об'єднань їх залучення до забезпечення національної безпеки як виду діяльності, що вимагає усвідомлення особливої відповідальності, розвиненого почуття обов'язку і високого ступеня організації, згуртованості і дисципліни, здатне стати дієвим фактором, що сприяє ефективності їх функціонування в питаннях статутної діяльності.

Завданням суспільства і органів влади має стати активне, систематичне і цілеспрямоване залучення громадських об'єднань, які відповідають критеріям безпеки і зарекомендували себе в якості ефективних кваліфікованих партнерів у цій сфері, до вирішення актуальних питань сучасного державного управління.

До пріоритетних напрямів оптимізації співробітництва органів державної влади та інститутів громадянського суспільства у сфері протидії загрозам правопорядку та соціально-політичної стабільності слід віднести творче використання громадських ініціатив, націлених на забезпечення національної безпеки;

- здійснення уніфікації структурної організації і розмежування сфери компетенції органів виконавчої та законодавчої влади на державному і регіональному рівнях, відповідальних за протидію загрозам безпеки;

- поширення практики співробітництва $з$ інститутами громадянського суспільства у сфері протидії кризовим процесам і небезпечних станів на діяльність всіх органів державного управління, зайнятих у сфері забезпечення різних аспектів безпеки, включаючи структури, призначені для ліквідації загроз неявного або прихованого характеру;

- проведення постійного моніторингу діяльності громадських об'єднань, які декларують свою прихильність забезпеченню різних аспектів безпеки, з метою виявлення їх реального потенціалу та відповідності діяльності нормам законодавства; 
- реалізація адміністративних і юридичних заходів націлених на формування в суб'єктів на принципах автономності, добровільності, колегіальності ефективних регіональних недержавних систем протидії загрозам безпеки і політичної стабільності.

- створення на регіональному рівні координуючих організацій, міжвідомчих комісій для проведення практичних заходів щодо об'єднання недержавних структур в єдину добровільну громадську організацію забезпечення національної безпеки, удосконалення юридичної бази, що регламентує міжнародні аспекти функціонування українських громадських об’єднань, які сприяють захисту національних інтересів.

Висновки. В статті досліджено види безпеки. Акцентовано увагу на безпеці життєдіяльності, національній безпеці. Досліджено законодавче регулювання питань забезпечення різних видів безпеки. Окреслено роль громадськості та громадських об'єднань в забезпеченні безпеки. В перспективі варто детально дослідити питання практичного забезпечення безпечного середовища для життя громадян.

\section{Стаття надійшла до редакції: 16.11.2018}

\section{CIVIL SOCIETY AS ONE OF THE MAIN ELEMENTS OF ANTI-CORRUPTION}

Hanna Fedorova, National University of life and environmental sciences of Ukraine

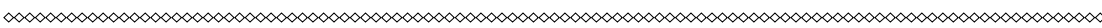

The legal state formation - a complex contradictory process. Along with the obvious achievements in the democratization of public life, liberalization of the economy, the development of Ukraine is characterized by the presence of destructive phenomena that significantly inhibit the implementation of socio-economic reforms that threaten the legitimate rights and interests of citizens, society and the state as a whole. Therefore, it is no coincidence that the increased attention of modern science to the problem of security. The search for solutions to the existing contradiction 
between the expected state of security and its actual implementation is one of the main tasks of the state.

Public associations in Ukraine are political and legal institutions that develop and perform an intermediary function between civil society and public authorities to ensure and protect the rights and freedoms of citizens, as well as their interests and initiatives. At the same time, in such an important problem for modern Ukraine as ensuring a safe environment, the interests of the state and society coincide. This is primarily due to the fact that the state owes its origin to society and develops with it. Therefore, it seems particularly relevant to study the interaction of the state in the face of its bodies with public associations in the field of security.

Experts and scientists in Ukraine are trying to find new effective ways to ensure national security, safety of life and the like. Representatives of civil society and all concerned citizens of Ukraine joined in these scientific developments. In particular, this article is directly related to the research of the Department of public administration and management of innovative activity of the UNI of postgraduate education of the National University of bioresources and nature management of Ukraine.

The article reveals the content load of the concepts "safety", "life safety», "civil control». The types of security are analyzed and it is established that the following types of security are distinguished: human security, national security, consisting of state security, security, political, economic, military, technological, environmental, humanitarian, demographic, information, banking, food, energy, etc.; safety of life activity, which components are: safety of work, safety of military service, public safety, food safety, personal safety, etc. The review of normative legal acts regulating the issues of security in the state, society and citizen safety. The components that provide a safe environment for the population of Ukraine are clarified.

Keywords: safe environment, safety, life safety, public, public safety.

\section{Received: 16.11.2018}




\section{References}

1. Zakon Ukrainy Pro natsionalnu bezpeku Ukrainy: pryiniatyi 21 chervnia 2018 r. № 2469-VIII. [Law of Ukraine on national security of Ukraine from June 21 2018, № 2469-VIII] Retrieved from http://zakon.rada.gov.ua/ laws/show/2469-19 [in Ukrainian]

2. Konstytutsiia Ukrainy. Pryiniata 30 ver. 2016 r. № 254k/96-VR. [Constitution of Ukraine from September 30 2016, № 254k/96-VR] Retrieved from http://search.ligazakon.ua/l_doc2.nsf/link1/Z960254K.html [in Ukrainian]

3. Zakon Ukrainy Pro hromadski obiednannia: pryiniatyi 22 zhovtnia 2018 r. № 2415-VIII. [Law of Ukraine on public associations from October 22 2018, № 2415-VIII] Retrieved from http://search.ligazakon.ua/1_doc2.nsf/ link1/T124572.html [in Ukrainian]

4. Pohorilko V. F. (2003) Publichna vlada. Yurydychna entsyklopediia: v 6 t. / red. Yu. S. Shemshuchenko ta in. K.: «Ukrain. entsykl. im. M. P. Bazhana», T. 5.736 s. [in Ukrainian]

5. Kolpakov V. K. ( 2012) Poniattia publichnoi administratsii. Stanovlennia derzhavy $\mathrm{v}$ umovakh hlobalizatsii: teoretychnyi ta praktychnyi aspekt: materialy II Mizhnar. nauk. konf. (m. Kyiv, 24 liut. 2012 r.). K., S. 135137. [in Ukrainian]

6. Kuzmenko O. V. (2018) Pravova determinatsiia poniattia «publichne administruvannia». Retrieved from http://www.pravnuk.info/2013-12-27-1513-45/529-pravova-determinaciya-ponyattya-publichne-administruvannya. html [in Ukrainian]

7. Zakon Ukrainy Pro natsionalnu bezpeku Ukrainy: pryiniatyi 8 lypnia 2018 p. № 2469-VIII. [Law of Ukraine on national security of Ukraine from June 8 2018, № 2469-VIII]. Retrieved from http://search.ligazakon.ua/1_doc2. nsf/link1/T182469.html [in Ukrainian]

8. Shevchenko L. V. (2012) Publichne administruvannia v sferi tsyvilnoho zakhystu naselennia: dys. kand. yuryd. nauk: 12.00.07. Extended abstract of candidate's thesis. K., Nats. akad. vnutr. sprav. 244 s. [in Ukrainian] 


\section{Відомості про авторів / Information about the Authors}

Федорова Анна Миколаївна: Національний університет біоресурсів та природокористування України: вул. Героїв Оборони, 15, Київ, 03041, Україна.

Hanna Fedorova: National University of life and environmental sciences of Ukraine: 15 Heroyiv Oborony str. Kiev, 03041, Ukraine.

ORCID. ORG/ 0000-0001-8833-6606

E-mail: 9949@i.ua 